\title{
SLAUGYTOJŲ VEIKLA SKATINANT NUTUKUSIUS PACIENTUS MAŽINTI KŪNO SVORI
}

\author{
Kristina Lingaité丶 \\ ${ }^{1}$ Lietuvos sveikatos moksly universiteto ligonine Kauno klinikos, Stuburo neurochirurgijos skyrius, \\ ${ }^{2}$ Lietuvos sveikatos moksly universiteto Slaugos fakultetas, Slaugos ir rüpybos katedra
}

Raktažodžiai: nutukimas, slaugytojų veikla, nutukimo valdymas, paciento motyvacija.

\section{Santrauka}

Tyrimo tikslas - nustatyti pirminiame sveikatos priežiūros centre (PSPC) dirbančių slaugytojų veiklą, skatinančią nutukusius pacientus mažinti kūno svorị. Tyrimo metodika. Atliktas vienmomentinis tikslinis tyrimas. Taikytas anketinès apklausos raštu tyrimo metodas. Naudota tyrèjų sudaryta 24 klausimų anketa. Tiriamieji - Kauno PSPC slaugytojai.

Tyrimo rezultatai. Tyrime dalyvavo 102 Kauno PSPC slaugytojai. Didžioji dauguma tyrimo dalyvių $(89,2$ proc.) skatino pacientus mažinti kūno svorị. Beveik pusè apklaustujų (48 proc.) skatino mažinti svorị antsvorio ir trečdalis $(32,4$ proc.) - I laipsnio nutukimo atvejais. Daugiau kaip pusè slaugytojų (52 proc.) fizinio aktyvumo rekomendacijas teikè kiekvieno apsilankymo metu. Dar daugiau slaugytoju rekomendavo pacientams užsiimti fizine veikla kasdien po 30 minučių $(67,6$ proc.) ir atlikti malonumą teikiančius fizinius pratimus (42,2 proc.). Patarimus sveikos mitybos klausimais pacientams teiké beveik visi slaugytojai ( 92,2 proc.). Mažinti kūno svorị motyvavo supažindindami su ligomis, kurių rizikos veiksnys yra nutukimas (93,1 proc.) ir nutukimo komplikacijos (66,7 proc.). Dauguma apklaustujų mano, kad gydytojai (40,2 proc.) arba išplèstinès praktikos slaugytojai (39,2 proc.) turetų būti atsakingi už pacientų mokymą gerinti savo sveikatos būklę ir kontroliuoti kūno svorị.

Išvados. Dauguma slaugytojų sveikos mitybos ir fizinio aktyvumo rekomendacijas teikè tik turintiems antsvorio ir esant I laipsnio nutukimui. Slaugytojai motyvavo nutukusius pacientus mažinti kūno svorị, supažindindami su nutukimo komplikacijomis ir ligomis, tačiau neorganizavo praktinių kūno svorio valdymo užsièmimų. Dauguma slaugytoju nurodè, kad gydytojai arba išplèstinès praktikos slaugytojai turètų būti atsakingi už pacientų mokymą gerinti savo sveikatos būklę ir kontroliuoti kūno svorị.

\section{Ivadas}

Pasaulio sveikatos organizacija (PSO) antsvorị ir nutukimą apibrèžia kaip nenormalų ar per didelį asmens sukauptą riebalų kiekị, keliantį pavojų sveikatai. Pasaulyje nuo 1975 m. nutukusių žmonių skaičius padidejjo beveik tris kartus. $2016 \mathrm{~m}$. daugiau kaip 1,9 mlrd. suaugusiųjų turejo antsvorio, iš jų daugiau kaip $650 \mathrm{mln}$. buvo nutukę [1]. Manoma, jei nutukimo paplitimo tempai augs taip sparčiai kaip dabar, tai $2030 \mathrm{~m}$. beveik pusè pasaulio suaugusių žmonių turès antsvorio ar bus nutukę [1]. Nutukimas laikomas viena iš pagrindinių pasaulio ekonomikos problemų, nes su juo susijusios išlaidos, patiriamos gydant vaikus ir suaugusius asmenis, siekia apie 2 trilijonus dolerių. Šios išlaidos sudaro 2,8 proc. pasaulio bendrojo vidaus produkto, o tai atitinka rūkymo, ginkluoto smurto, karo ar terorizmo sukeliamus finansinius nuostolius pasaulio ekonomikai [2].

Per dvidešimt metų (1994-2014 m.) Lietuvoje antsvorio paplitimas tarp vyrų padidejjo nuo 47 iki 59 proc., o nutukimo - nuo 10 iki 19 procentų. Turinčių antsvorio ir nutukusių moterų skaičius praktiškai beveik nepakito [3].

Tyrejai nurodo, kad nutukimo riziką didina per didelis su maistu suvartojamų kalorijų kiekis, nes daugeja greitojo maisto pardavimo įstaigų, siūlomos didesnès maisto porcijos už mažesnę kainą, vykdoma veiksminga prekybos reklama. Nutukimą skatina ir fizinis pasyvumas $[1,4]$. Nepakankamą Lietuvos gyventojų fizini aktyvumą patvirtina ir $2014 \mathrm{~m}$. Europos Parlamento apklausos duomenys. Nustatyta, kad visiškai nesimankština ir nesportuoja apie 46 proc. suaugusių Lietuvos gyventojų. Šis skaičius yra 4 proc. mažesnis už Europos Sajungos vidurkị (ES vidurkis - 42 proc.) [5].

Nutukimo prevencijai būtina skatinti Lietuvos gyventojus sveikiau gyventi. Slaugytojai, dirbantys PSPC, galètų akty- 
viau ịsitraukti į sveikos gyvensenos propagavimą, nes sudaro didelę sveikatos priežiūros specialistų grupę [6]. K. Phillips ir kt. (2014) nustatė, kad slaugytojai, dirbantys pirminejje sveikatos priežiūroje, gali veiksmingai konsultuoti pacientus nutukimo valdymo klausimais [6]. Gyvensenos pokyčiams didelę ịtaką turi pacientų motyvacija [7], todèl slaugytojai turi būti pasirengę stiprinti nutukusių ar antsvorio turinčių žmonių motyvaciją sveikai gyventi ir mažinti kūno svorį.

Tyrimo tikslas - nustatyti PSPC dirbančių slaugytojų veiklą, skatinančią nutukusius pacientus mažinti kūno svorị.

\section{Tyrimo medžiaga ir metodai}

Tyrimas atliktas $2018 \mathrm{~m}$. lapkričio - gruodžio ménesiais viename Kauno PSPC, gavus Lietuvos sveikatos mokslų universiteto Bioetikos centro leidimą. Atliktas vienmomentinis tikslinis tyrimas, anketinè apklausa raštu.

Tyrime dalyvavo 102 slaugytojai, dirbantys Kauno PSPC.

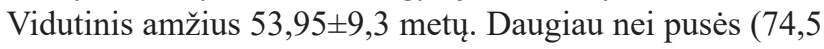
proc.) išsilavinimas aukštesnysis, 16,7 proc. sudarẻ slaugytojai, turintieji aukštaji neuniversitetinį, 8,8 proc. - aukštajj universitetinị išsilavinimą. Daugiau kaip 30 metų PSPC

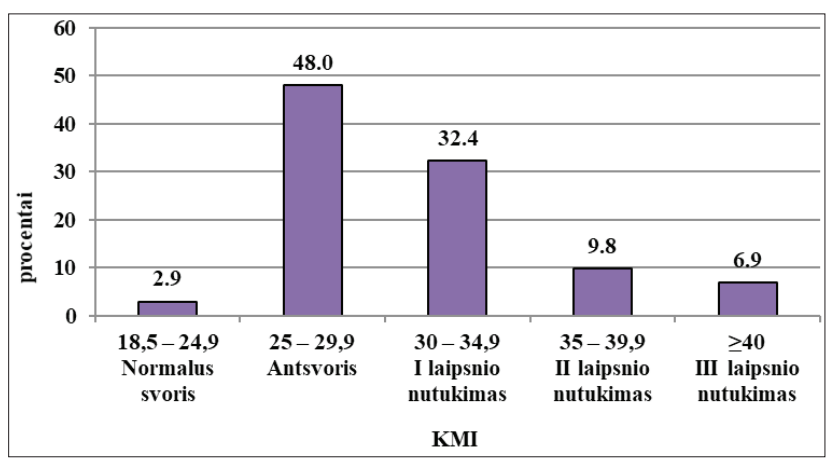

1 pav. Slaugytojų pasiskirstymas pagal pacientų skatinimą mažinti svorị priklausomai nuo pacientų kūno masès indekso (KMI).

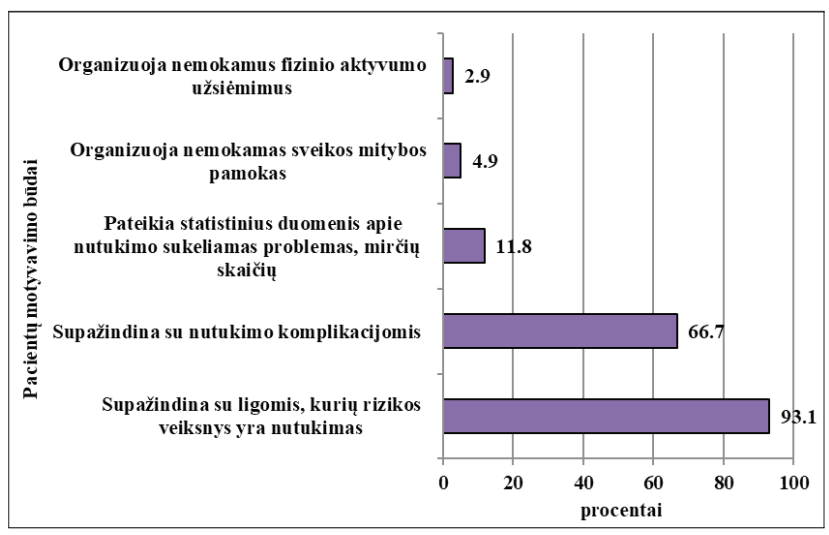

2 pav. Slaugytojų pasiskirstymas pagal motyvavimo būdus mažinti svori, nutukusiems/turintiems antsvorio pacientams. dirbo 39,2 proc. slaugytojų, trečdalis (33,3 proc.,) dirbo 21 30 metų ir 20 metų $-27,5$ proc. slaugytojų.

Tyrimui naudota tyrejų sudaryta 24 klausimų anketa. Atsakymai ị pateiktuosius klausimus turejo suteikti informacijos, ar slaugytojai skatina pacientus mažinti svorį, ar teikia rekomendacijas fizinio aktyvumo ir sveikos mitybos klausimais, kaip motyvuoja pacientus keisti gyvensenos ịpročius, kas PSPC turètų būti atsakingas už pacientų mokymą gerinti savo sveikatos būklę ir kontroliuoti kūno svorị. Prieš pradedant apklausą, atliktas žvalgomasis tyrimas, kurio metu slaugytojų ( $\mathrm{n}=10)$ prašyta ịvertinti klausimų suprantamumą. Pagal pateiktas pastabas pakoreguota keletas klausimų ir atliktas pagrindinis duomenų rinkimas.

Statistinè duomenų analizė atlikta naudojant kompiuterinès programos statistikos paketą , SPSS/w 24.0“. Nagrinejjamų požymių pasiskirstymui pasirinktoje imtyje ịvertinti taikyta aprašomoji duomenų statistika - absoliutūs (n) ir procentiniai dažniai (proc.).

1 lentelè. Slaugytojų pasiskirstymas pagal nutukusiems/ turintiems antsvorio pacientams, teikiamas fizinès veiklos rekomendacijas.

\begin{tabular}{|l|c|}
\hline $\begin{array}{l}\text { Slaugytojų teikiamos fizinės veiklos } \\
\text { rekomendacijos pacientams }\end{array}$ & n (proc.) \\
\hline Teikiamų rekomendacijų dažnis: & \\
\hline Kiekvieno apsilankymo metu & $53(52,0)$ \\
\hline Kas kelis mènesius & $32(31,4)$ \\
\hline Kai paprašo pacientas & $11(10,8)$ \\
\hline Nerekomenduoja & $6(5,8)$ \\
\hline Rekomenduojamas fizinės veiklos laikas: & \\
\hline Kasdien iki 15 min. & $16(15,7)$ \\
\hline Kasdien po 30 min. & $69(67,6)$ \\
\hline Kas 2 dienas po 30 min. & $11(10,8)$ \\
\hline Nerekomenduoja & $6(5,9)$ \\
\hline Rekomenduojamas fizinės veiklos pobūdis: & \\
\hline Lengvas fizinis aktyvumas & $33(32,4)$ \\
\hline Vidutinis fizinis aktyvumas & $26(25,4)$ \\
\hline Malonumą teikiantis fizinis aktyvumas & $43(42,2)$ \\
\hline
\end{tabular}

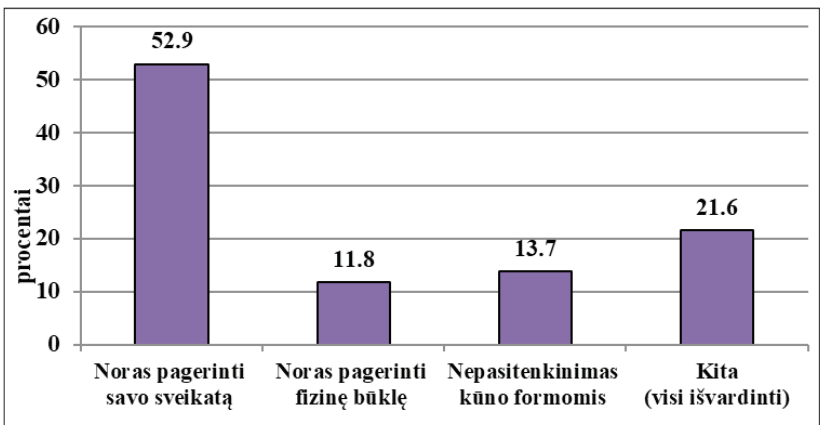

3 pav. Slaugytojų nuomonès pasiskirstymas apie pacientus motyvuojančias priežastis mažinti svorị. 


\section{Tyrimo rezultatai}

Tyrimo rezultatai parodè, kad didžioji dauguma slaugytojų ( 89,2 proc., $\mathrm{n}=91)$ skatina pacientus mažinti svorị ir tik 10,8 proc. $(\mathrm{n}=11)$ neskatina. Beveik pusè slaugytojų $(48,0$ proc., $\mathrm{n}=49$ ) pacientus, kurių kūno masès indeksas (KMI) yra 25-29,9 (antsvoris), skatina mažinti svorị. Trečdalis slaugytojų $(32,4$ proc., $n=33)$ rekomenduoja mažinti svorị esant I laipsnio nutukimui, o dešimtadalis $(9,8$ proc., $n=10)$ - esant II laipsnio nutukimui (1 pav.).

Tyrimo metu siekta išsiaiškinti, kokias fizinio aktyvumo rekomendacijas slaugytojai teikia turintiems antsvorio ir nutukusiems pacientams. Nustatyta, kad daugiau kaip puse slaugytojų (52,0 proc., $\mathrm{n}=53$ ) kiekvieno apsilankymo metu rekomenduoja pacientams užsiimti fizine veikla, trečdalis $(31,4$ proc., $n=32)-$ kartą per keletą mėnesių. Dažniausiai rekomenduojamas fizinès veikos laikas $-(67,6$ proc., $n=69)$ kasdien bent po 30 minučių. Beveik pusè slaugytojų (42,2 proc., $n=43$ ) kiekvienam turinčiam antsvorio ar nutukusiam asmeniui rekomenduoja užsiimti individualia, jam malonumą teikiančia fizine veikla, trečdalis $(32,4$ proc., $\mathrm{n}=33)$ rekomenduoja lengvą fizinị aktyvumą ir tik ketvirtadalis $(25,4$ proc., $\mathrm{n}=26$ ) - vidutini fizini aktyvumą (1 lentelè).

Sveikos mitybos rekomendacijas nutukusiems ir turintiems antsvorio pacientams teikia beveik visi slaugytojai ( 92,2 proc., $\mathrm{n}=94)$. Beveik pusè apklaustujų (43,6 proc. $\mathrm{n}=41)$ visada teikia rekomendacijas dèl cukraus kiekio mažinimo. Slaugytojų teikiamų sveikos mitybos rekomendacijų nutukusiems ir turintiems antsvorio pacientams pobūdis ir dažnis pateikiamas 2 lentelèje.

Skaičiuoti kalorijas pacientus mokè mažiau kaip pusė apklaustujų $(38,2$ proc., $\mathrm{n}=39)$, o didžioji dalis $(61,8$ proc., $\mathrm{n}=63)$ - nemokè.

İvertinus slaugytojų taikomus motyvus mažinti kūno svorị, nustatyta, kad dažniausiai motyvuojama supažindinant su ligomis, kurių rizikos veiksnys yra nutukimas $(93,1$ proc., $\mathrm{n}=95$ ) ir su nutukimo komplikacijomis $(66,7$ proc., $n=68)$. Nemokamas sveikos mitybos pamokas organizuoja tik 4,9 proc. $(\mathrm{n}=5)$ slaugytojų, o nemokamus fizinio aktyvumo užsièmimus - tik 2,9 proc. $(n=3)$ apklaustujų (2 pav.)

Slaugytojų nuomone, mažinti kūno svorị pacientus labiausiai motyvuoja noras pagerinti savo sveikatą (52,9 proc., $\mathrm{n}=54)$. Nedidelè dalis slaugytojų nurode, kad mažinti kūro svorị motyvuoja noras pagerinti fizinę būklę (11,8 proc., $\mathrm{n}=12)$ ir nepasitenkinimas kūno formomis (13,7 proc., $n=14$ ) (3 pav.).

Dauguma apklaustųjų nurodè, kad pirminèje sveikatos priežiūros grandyje už pacientų mokymą gerinti savo sveikatos būklę ir kontroliuoti kūno svorị turètų būti atsakingi gydytojai ( 40,2 proc., $n=41)$, arba išplèstinès praktikos slaugytojai (39,2 proc., $n=40)$. Tik nedidelè dalis $(15,7$ proc. $\mathrm{n}=16$ ) nurodè, kad už tai turètų būti atsakingi slaugytojai (4 pav.).

\section{Diskusija}

Nutukimas yra sparčiai didejjanti problema, kuri sukelia ịvairius žmogaus sveikatos sutrikimus [2]. PSO nurodo šias nutukimo pasekmes: širdies ir kraujagyslių ligos, II tipo cukrinis diabetas, kai kurios véžio formos ir kitų lètinių ligu rizika [1]. Nutukimas sudaro 5 proc. mirties priežasčių pasaulyje ir yra svarbi pasaulio ekonomine problema [2]. PSO nutukimą apibūdina kaip pasaulinio masto epidemiją [1].

K. Philips ir kt. (2014) nurodo, kad nutukimo prevencijoje gali aktyviai dalyvauti pirminès sveikatos priežiūros slaugytojai, nes kai kurie pacientai neturi tinkamų žinių ir nesupranta bendrujų sveikos mitybos ir fizinio aktyvumo principų, todèl negali jų taikyti savo gyvensenai [6]. Mūsų

2 lentelè. Slaugytojų pasiskirstymas pagal nutukusiems/turintiems antsvorio pacientams suteikiamas sveikos mitybos rekomendacijas ( $\mathrm{n}=94)$.

\begin{tabular}{|l|c|c|c|c|c|}
\hline Teiginiai & $\begin{array}{c}\text { Visada } \\
\text { n (proc.) }\end{array}$ & $\begin{array}{c}\text { Labai } \\
\text { dažnai } \\
\text { n (proc.) }\end{array}$ & $\begin{array}{c}\text { Dažnai } \\
\text { n (proc.) }\end{array}$ & $\begin{array}{c}\text { Retai } \\
\text { n (proc.) }\end{array}$ & $\begin{array}{c}\text { Labai } \\
\text { retai } \\
\text { n (proc.) }\end{array}$ \\
\hline $\begin{array}{l}\text { Suvartoti 400g daržovių } \\
\text { ir vaisių per dieną. }\end{array}$ & $24(25,5)$ & $19(20,2)$ & $47(50,0)$ & $3(3,2)$ & $1(1,1)$ \\
\hline $\begin{array}{l}\text { Valgomosios druskos } \\
\text { kiekị sumažinti iki 5g } \\
\text { per dieną. }\end{array}$ & $24(25,5)$ & $18(19,1)$ & $36(38,3)$ & $\begin{array}{c}12 \\
(12,8)\end{array}$ & $4(3,9)$ \\
\hline $\begin{array}{l}\text { Skaidulinių medžiagų } \\
\text { per dieną vartoti 20-30 g }\end{array}$ & $17(18,1)$ & $16(17,0)$ & $37(39,3)$ & $\begin{array}{c}15 \\
(16,0)\end{array}$ & $9(9,6)$ \\
\hline $\begin{array}{l}\text { Angliavandeniai turi su- } \\
\text { daryti 55-75 proc. paros } \\
\text { maisto davinio energeti- } \\
\text { nės vertės. }\end{array}$ & $8(8,5)$ & $5(5,3)$ & $36(38,3)$ & $\begin{array}{c}17 \\
(18,1)\end{array}$ & $28(29,8)$ \\
\hline $\begin{array}{l}\text { Baltymai turi sudaryti } \\
\text { 10-15 proc. paros maisto } \\
\text { davinio energetinės ver- } \\
\text { tės. }\end{array}$ & $8(8,5)$ & $11(11,7)$ & $35(37,2)$ & $\begin{array}{c}16 \\
(17,0)\end{array}$ & $24(25,5)$ \\
\hline $\begin{array}{l}\text { Riebalai turi sudaryti 15- } \\
\text { 30 proc. paros maisto da- } \\
\text { vinio energetinès vertess. }\end{array}$ & $10(10,6)$ & $10(10,6)$ & $33(35,1)$ & 15 & $26(27,7)$ \\
\hline $\begin{array}{l}\text { Per dieną valgyti 3-4 } \\
\text { kartus. }\end{array}$ & $29(30,9)$ & $29(30,9)$ & $28(29,8)$ & $6(6,3)$ & $2(2,1)$ \\
\hline $\begin{array}{l}\text { Mažinti suvartojamo cu- } \\
\text { kraus kiekị. }\end{array}$ & $41(43,6)$ & $28(29,8)$ & $23(24,5)$ & $2(2,1)$ & - \\
\hline
\end{tabular}


tyrimo rezultatai parode, kad dauguma (89,2 proc.) PSPC slaugytojų skatina pacientus mažinti svorị, tačiau dažniausiai tuos, kurie turi antsvorio arba esant I laipsnio nutukimui. Tik nedaugelis skatina mažinti svorį esant II ir III laipsnio nutukimui. Galima teigti, kad slaugytojai tikisi, jog pacientai susirūpins savo sveikata esant mažesniam nutukimo laipsniui ar antsvoriui, nei esant II ir III laipsnio nutukimui.

Mokslinès literatūros duomenimis, siekiant pagerinti fizini aktyvumą, rekomenduojama kasdien mankštintis bent po 30 minučių [8-11]. Tyrimo rezultatai parodè, kad tik pusė PSPC slaugytojų aktyviai motyvuoja pacientus užsiimti fizine veikla, kiekvieno apsilankymo metu teikdami fizinio aktyvumo rekomendacijas. Daugiausiai slaugytojų rekomenduoja užsiimti fizine veikla kasdien po 30 minučių. Nutukusiems pacientams slaugytojai rekomenduoja skirtingą fizinès veiklos pobūdị. Beveik pusė slaugytojų (42.2 proc.) rekomenduoja pacientams malonumą teikiantị fizinị aktyvumą, kiti - lengvą arba vidutinị fizinị aktyvumą. Galima teigti, kad slaugytojai šias rekomendacijas teikia atsižvelgdami i paciento KMI ir amžių. Mokslinėje literatūroje taip pat galime rasti ivvairios fizinio aktyvumo informacijos. Vieni autoriai rekomenduoja pradèti nuo nedidelio fizinio aktyvumo ir palaipsniui didinti trukmę, dažn̨ ir intensyvumą [12], kiti - pasirinkti prieinamiausią ir didžiausią malonumą teikiančią fizinio aktyvumo formą (vaikščiojimą, važiavimą dviračiu, plaukimą, futbolą, tinklinį ar krepšinị ir t.t. ) [10], o PSO pateikia fizinio aktyvumo rekomendacijas pagal amžiaus grupes [11].

Tyrimo rezultatai parode, kad patarimus sveikos mitybos klausimais pacientams teikia beveik visi slaugytojai $(92,2$ proc.), tačiau tik nedaugelis ( 38,2 proc.) šiuos patarimus teikia nuolat ir moko skaičiuoti kalorijas. B.L. James ir kt. (2018) teigimu, ilgalaikiam svorio mažinimui yra veiksmingas ne tik porcijų mažinimas ir sveiko maisto pasirinkimas,

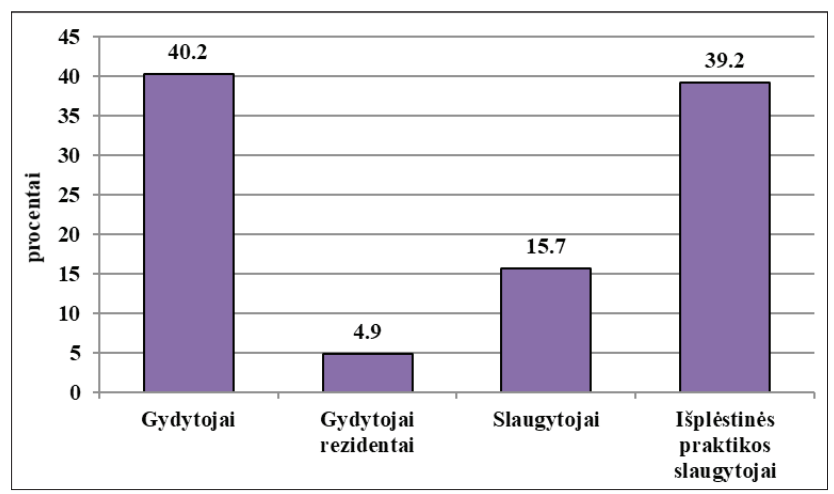

4 pav. Slaugytojų nuomonės pasiskirstymas apie asmenis, atsakingus už pacientų mokymus sveikatos būklei gerinti ir svoriui kontroliuoti PSPC. bet ir kalorijų skaičiavimas pagal energijos poreiki [13]. Galima teigti, kad tyrime dalyvavę slaugytojai dèl didelio darbo krūvio neturi laiko išsamiai paaiškinti kalorijų skaičiavimo metodikos arba stokoja žinių šia tema, tačiau tai patvirtinti reikalingi slaugytojų žinių tyrimai.

R. Schwarzer ir kt. (2008) teigimu, žmogus turi būti motyvuotas keisti mitybos ịpročius [7]. Tyrime dalyvavę slaugytojai nurode, kad jie stengiasi motyvuoti nutukusius ir turinčius antsvorio pacientus mažinti kūno svorị. Motyvacijos priemonès - supažindinimas su ligomis, kurių rizikos veiksnys yra nutukimas ir su nutukimo komplikacijomis. Praktinius sveikos mitybos ir fizinio aktyvumo užsièmimus organizuoja labai maža dalis slaugytojų. Galima priežastis - dideli PSPC slaugytojų darbo krūviai arba slaugytojai jaučiasi nekompetentingi vykdyti praktinius sveikos gyvensenos mokymus.

E.H. Evans ir kt. (2018) atliktas tyrimas parode, kad labiausiai pacientus motyvuojantys veiksniai mažinti kūno svori yra sveikatos gerinimas ( 77,0 proc.), nepasitenkinimas kūno formomis $(64,0$ proc.) ir noras pagerinti fizinę būklę (55,0 proc.) [14]. Mūsų tyrime dalyvavę slaugytojai nurodè tuos pačius motyvuojančius veiksnius: nepasitenkinimas kūno formomis, noras pagerinti savo sveikatą ir fizinę būklę.

Slaugytojų nuomone, už sveikatos būklès gerinimą ir svorio kontrolę turètų būti atsakingi PSPC gydytojai, išplèstinès praktikos slaugytojai arba slaugytojai. Galima teigti, kad ateityje PSPC dirbantys išplèstinès praktikos slaugytojai aktyviai skatins nutukusius pacientus sveikai gyventi, nes šiuo metu Lietuvoje išplèstinès praktikos slaugytojų, igijusių pirminès sveikatos priežiūros specializaciją, parengta nedaug.

Apibendrinant galima teigti, kad dauguma slaugytojų skatina pacientus, turinčius antsvorio ir esant I laipsnio nutukimui, mažinti kūno svorị, tačiau tai daro ne kiekvieno apsilankymo metu. Tinkamus patarimus sveikos mitybos tema ir fizinès veiklos rekomendacijas suteikia tik dalis slaugytojų. Slaugytojai nurodo, kad pirminèje sveikatos priežiüros grandyje už pacientų mokymą gerinti savo sveikatos būklę ir kontroliuoti kūno svorị turi būti atsakingi gydytojai arba išplèstinès praktikos slaugytojai.

\section{Išvados}

1. Dauguma slaugytojų teikia sveikos mitybos ir fizinio aktyvumo rekomendacijas turintiems atsvorio pacientams, ar esant I laipsnio nutukimui.

2. Slaugytojai motyvuoja nutukusius pacientus mažinti kūno svorí, supažindindami su nutukimo komplikacijomis ir ligomis, tačiau neorganizuoja praktinių kūno svorio valdymo užsièmimų.

3. Dauguma slaugytojų nurodo, kad gydytojai arba išplèstinès praktikos slaugytojai turètų būti atsakingi už pa- 
cientų mokymą gerinti savo sveikatos būklę ir kontroliuoti kūno svorị.

\section{Literatūra}

1. World Health Organization. Obesity and overweight. In: media Centre. World health Organization [Internet] 2018. http:// www.who.int/en/news-room/fact-sheets/detail/obesity-andoverweight.

2. Dobbs R, Sawers C, Thompson F, Manyika J, Woetzel J, Child P McKenna S, Spatharou A. Overcoming obesity: an initial economic analysis. McKinsey Global Institute 2014;111.

3. Grabauskas V., Klumbienė J., Petkevičienė J., Šakytė E., Kriaučionienė V., Veryga A. Suaugusių Lietuvos žmonių gyvensenos tyrimas, 2014. Lietuvos sveikatos mokslų universitetas, 2015;1-147.

4. Branca F, Nikogosian H, Lobstein T. The challenge of obesity in the WHO European region and the strategies for response.WHO Regional Office for Europe: Copenhagen 2007:21-22, 46.

5. European Comision. Special Eurobarometer 412. Sport and physical activity. Report [Internet] 2014;7. http://ec.europa. eu/health/nutrition_physical_activity/docs/ebs_412_en.pdf

6. Phillips K, Wood F, Kinnersley P. Tackling obesity: the challenge of obesity management for practice nurses in primary care. Family Practice 2014;31(1):51-9.

https://doi.org/10.1093/fampra/cmt054

7. Schwarzer R. Modelling health behaviour change: how to predict and modify the adoption and maintenance of health behaviours. Applied Psychology: An international Review 2008;57(1): 1-29. https://doi.org/10.1111/j.1464-0597.2007.00325.x

8. Bagdonas G. Arterinė hipertenzija senyvame amžiuje. Lietuvos bendrosios praktikos gydytojas, 2009; 13(5): 330-336.

9. Ovčinikova A., Jatužis D. Insulto rizikos veiksniai ir jų profilaktika. Lietuvos gydytojo žurnalas, 2014;3:4-9.

10. Bartkevičiūte R., Barzda A., Stukas R., Abaravičius A., Petkevičienè J., Klumbienė J. Sveikos mitybos metodinès rekomendacijos. Sveikatos mokymo ir ligų prevencijos centras, 2010;7-23. http://www.smlpc.lt/media/file/Skyriu_info/Metodine_medziaga/Sveikos_mitybos_rekomendacijos_2010.pdf.

11. World Health Organization. Global Strategy on Diet, Physical Activity and Health. Physical Activity [Internet] 2019. https://www.who.int/dietphysicalactivity/pa/en/

12. Janonienė R., Sobutienė A., Valintèlienè R. Fizinio aktyvumo matavimo metodai. Visuomenès sveikata, 2014;3(66):10-21.

13. James BL, Roe LS, Loken E, Rolls BJ. Early predictors of weight loss in a 1-year behavioural weight-loss programme.
Obesity Science \& Practice 2018;4(1):20-8.

https://doi.org/10.1002/osp4.149

14. Evans EH, Sainsbury K, Kwasnicka D, Bolster A, Araujo-Soares V, Sniehotta FF. Support needs of patients with obesity in primary care: a practice-list survey. BMC Family Practice 2018;19(1):2-9.

https://doi.org/10.1186/s12875-017-0703-4

\section{ACTIVITIES OF NURSES TO PROMOTE OBESE PATIENTS TO LOSE BODY WEIGHT \\ K.Lingaitė, D.Kriukelytė, J.Gulbinienė}

Keywords: obesity, nursing intervention, obesity management, patient motivation.

Summary

The aim of the study was to assess the activities of nurses to promote obese patients to lose body weight.

Material and Method. A quantitative study with the anonymous survey was conducted at Kaunas X primary health care centre (PHC). The subjects were nurses working at the Kaunas X PHC Centre. The study was conducted using a 24-item questionnaire designed by the researchers to identify the role of the nurses to promote obese patients to lose weight.

Results. A 102 nurses working at Kaunas X PHC Centre participated in the study. The majority of nurses (89.2\%) encouraged patients to lose weight. Most nurses promoted weight loss for overweighed (48\%) and Class 1 obesity (32.4\%) patients. Most nurses made physical activity recommendations at each visit $(52 \%)$. Most nurses $(67.6 \%)$ recommended patients to do daily 30 minutes exercise and physical exercise for their own pleasure (42.2\%). Almost all nurses $(92.2 \%)$ gave advice on healthy eating to patients. Patients were motivated to lose weight by familiarizing themselves with obesity-related diseases $(93.1 \%)$ and obesity complications $(66.7 \%)$.Most respondents believed that doctors (40.2\%) or advanced care nurses $(39.2 \%)$ should be responsible for educating patients on health improvement and weight control.

Conclusions. Most nurses provided guidance on healthy eating and physical activity only in overweight and Class 1 obese patients. Nurses motivated obese patients to lose weight by learning about the complications and illnesses of obesity, but they did not organized workshops on weight management. Most nurses pointed out that doctors or advanced practice nurses should be responsible for educating patients on health improvement and weight control.

Correspondence to: lingaite.kristina@gmail.com

Gauta 2019-09-13 